\title{
Kernos
}

Revue internationale et pluridisciplinaire de religion grecque antique

$23 \mid 2010$

Varia

\section{A Greek Magical Gemstone from the Black Sea}

Amulet or Miniature Handbook?

\section{Christopher A. Faraone}

\section{Q OpenEdition \\ 1 Journals}

\section{Electronic version}

URL: http://journals.openedition.org/kernos/1569

DOI: 10.4000/kernos.1569

ISSN: 2034-7871

\section{Publisher}

Centre international d'étude de la religion grecque antique

\section{Printed version}

Date of publication: 1 January 2010

Number of pages: 91-114

ISSN: 0776-3824

\section{Electronic reference}

Christopher A. Faraone, « A Greek Magical Gemstone from the Black Sea », Kernos [Online], 23 | 2010,

Online since 10 October 2013, connection on 19 April 2019. URL : http://journals.openedition.org/ kernos/1569 ; DOI : 10.4000/kernos.1569 


\title{
A Greek Magical Gemstone from the Black Sea: Amulet or Miniature Handbook?*
}

\begin{abstract}
A neglected agate gemstone from Anapa, which dates to the Roman imperial period, is of great interest, as it differs from most magical gems in its spherical shape, its large size and its contents: it begins with a reference to traditional Greek expulsion rituals and ends with a list of the parts of the human head similar to that found in a Hippocratic medical handbook. I argue that the gem is not an amulet, as previous editors have assumed, but rather a miniature handbook with instructions for making amulets.

Résumé : Une gemme en agate peu étudiée provenant d'Anapa, datée de la période impériale, présente un grand intérêt, dans la mesure où elle diffère de la plupart des gemmes magiques par sa forme sphérique, sa grande taille et son contenu : elle commence par une référence aux rituels traditionnels grecs d'expulsion et se termine par une liste des parties de la tête humaine semblable à celle que l'on trouve dans un manuel médical hippocratique. La gemme ne serait pas une amulette, comme les éditeurs précédents l'ont supposé, mais plutôt un manuel miniature contenant des instructions pour la fabrication d'amulettes.
\end{abstract}

Nearly thirty years ago Oleg Neverov republished an agate gemstone from the Historical Museum of Anapa, ${ }^{1}$ a Russian city that lies on the north coast of the Black Sea, about fifty miles east of the entrance to the Sea of Azov. The gem dates to the Roman imperial period and was presumably found among the nearby

* I presented different versions of this paper at the Ancient History Seminar of the Institute for Advanced Study in Princeton in November 2008 and at the Workshop for Ancient Societies at the University of Chicago in January 2009 and I am grateful to the audiences and colleagues in both places for their comments and questions. All of the flaws that remain are, of course, my own. I began this essay at the Institute for Advanced Study in Princeton on a fellowship supported by a grant from the Andrew W. Mellon Foundation as well as the Hetty Goldman Membership Fund and I completed it as a Fellow at the Getty Research Institute in Malibu, California. I am extremely grateful to these institutions for my support and to the dedicated staff, librarians and curators who made my work especially fruitful and pleasant. - I would like to thank Dr. Melnikova Irina Nikolaevna, the Director of the Anapa Historical Museum, for the new photographs of the gem and for permission to use them, and to Prof. Vladimir F. Stolba for his crucial help in contacting the museum and arranging for the photographs to be taken and sent.

${ }^{1}$ Inv. 835. The photographs in Figures 1 and 2 are from BlavatSKajA (1958), p. 231. For brief discussion see NEVEROV (1978), vol. 2., p. 833-48, no. 50, plate clxxvi, who dates the text to

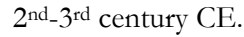


ruins of ancient Gorgippia, a Greek city that flourished for more than half a millennium between the third century BCE and the third century CE. ${ }^{2}$ The gem is of great interest, as it differs from most magical gems in its spherical shape (see Fig. 1-2), its large size (3.5 $\mathrm{cm}$ in diameter) and its contents: it begins with a reference to traditional Greek expulsion rituals and ends with a list of the parts of the human head similar to that found in a Hippocratic medical handbook.

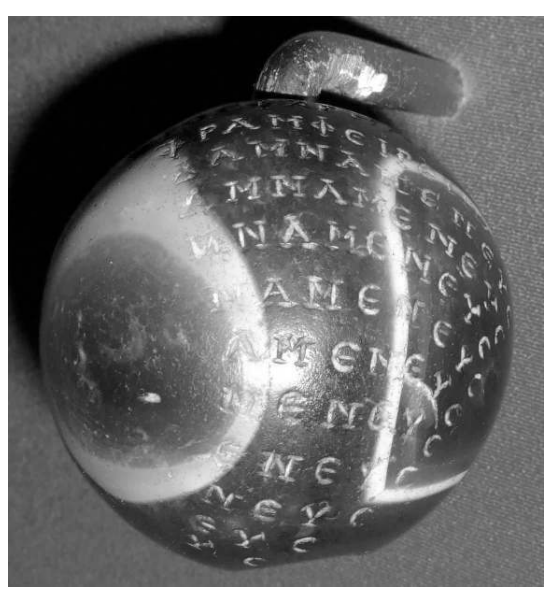

Fig. 1

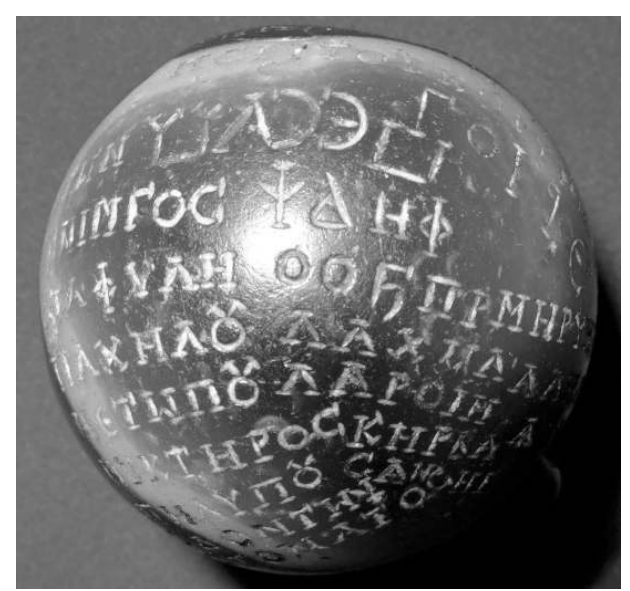

Fig. 2

Because the text on the gem includes a prayer for healing and health, there is a good possibility that the gem was designed as an amulet, but I shall argue below that it was most probably used by a professional magician as a miniature handbook and a model for making a variety of amulets for healing the diseases of the head.

\section{The Text}

Despite the unusual spherical shape of the stone, which is inscribed at every point on its surface, the inscriptions can be divided sensibly into two coherent groups, each twelve lines long: ${ }^{3}$

\footnotetext{
${ }^{2}$ Gorgippia was founded in the $6^{\text {th }}$ century BCE as a Greek emporium, grew to a prosperous city by the $3^{\text {rd }}$ century BCE, and was eventually destroyed by the Goths in $3^{\text {rd }}$ century CE.

${ }^{3}$ I give the text of Blavatskaja and Neverov, who disagree only at the points noted in the

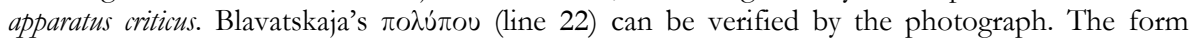

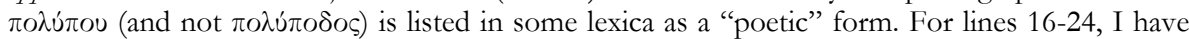
inserted a vertical space to indicate the division between two columns of text. On the stone, however, these columns are differentiated not by space, but by a change in the direction of the writing, as one can see in figure 2.
} 
OBVERSE:

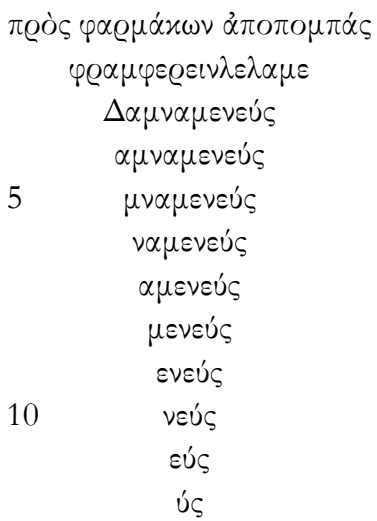

\section{REVERSE:}

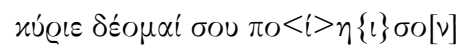

$\tau \dot{\eta} \mu \mu \dot{\alpha} \theta \eta \nu \dot{\alpha} x \dot{\eta} \nu$ i $\gamma \varepsilon i \eta \eta \gamma^{4}$

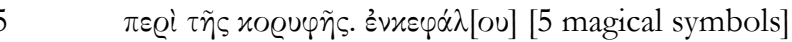

\begin{tabular}{|c|c|}
\hline$\omega^{\prime \prime} \tau \omega \nu$ & [6 magical symbols] \\
\hline 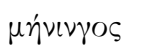 & {$[4 \text { magical symbols }]^{5}$} \\
\hline$\sigma \tau \alpha \varphi \dot{u}^{\prime} \lambda[s]$ & {$\left[3\right.$ magical symbols] $\pi \varrho \mu \eta \varrho \cup \mu \alpha^{6}$} \\
\hline$\tau \varrho \alpha \chi \eta^{\prime} \lambda \circ v$ & $\lambda \alpha \chi \mu \alpha \lambda \eta \lambda$ \\
\hline$\mu \varepsilon \tau \omega^{\prime} \pi O \nu$ & $\lambda \alpha \varrho o \iota \mu \alpha \iota \alpha^{7}$ \\
\hline$\mu u x \tau \tilde{\eta} \varrho о \varsigma$ & $x \eta \varrho \varepsilon \alpha$ \\
\hline$\pi \circ \lambda \cup ́ \pi O u$ & $\sigma \alpha \eta \eta \imath$ \\
\hline 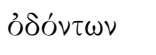 & [magical symbol] $^{8}$ \\
\hline$o ́ \mu \alpha \tau O \varsigma$ & \\
\hline
\end{tabular}

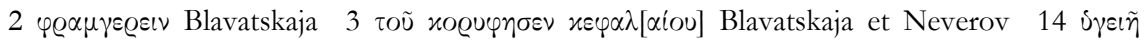
Blavatskaja $21 \lambda \alpha \chi \mu \lambda \alpha \lambda \alpha \eta \lambda$ Blavatskaja $22 \pi 0 \lambda \dot{\pi}$ ov Nemerov

${ }^{4}$ Blavatskaja (1958) prints iүein followed (after a space) by a symbol that looks like an enlarged gamma with a line coming up from the top.

${ }^{5}$ If we assume that in this line the engraver mistakenly carved a Roman A instead of an alpha (see also note 8 below), then the four symbols here might be interpreted as another magical name $\psi \propto \eta \varphi$, albeit inscribed in a format larger than that of the surrounding text.

${ }^{6}$ This group of Greek letters bunched at the end of line 18 probably constitute a magical nonsense name, but some have suggested to me per letteras that there may be a real Greek rubric buried here, e.g. $\pi \varrho(\grave{o} \varsigma) \mu \grave{\eta} \varrho \dot{u} \mu \alpha$ ("for the sake of no flux") Dean Jones or $\pi \varrho(\grave{o} \varsigma) \mu \dot{\eta} \varrho v<\sigma>\mu \alpha$ ("for a fracture") Kotansky. All of these suggestions would, however, break the consistent pattern of body part in the genitive followed by magical names or symbols.

${ }^{7}$ According to Blavatskaja (1958) the last three letters of this line $(\alpha<\alpha)$ are placed between lines 20 and 21 , beyond the end of both lines.

${ }^{8}$ This symbol is an oversized Roman A. 


\section{OBVERSE:}

For the sendings-away of $\varphi \alpha \dot{\alpha} \mu \alpha \varkappa \alpha$ :

phramphereinlelame

Damnameneus

amnameneus

5

mnameneus

nameneus

ameneus

meneus

eneus

10

neus

eus

us

REVERSE:

Lord, I beg of you, grant

the knowledge, healing, health, ${ }^{9}$

5 concerning the head. For the brain [5 magical symbols]

For the ears [6 magical symbols]

For the eardrum [4 magical symbols]

For the uvula [3 magical symbols] Prmêruma

For the throat Lachmalêl

20 For the forehead Laroimaia

For the nostril Kêrea

For the polyp Saêei

For the teeth [magical symbol]

For the mouth

\section{The rubric and the solar name}

The first line of the Obverse, which I translate somewhat awkwardly above as "For the sendings-away of $\varphi \alpha \varrho \mu \alpha \varkappa \alpha$," seems to be a rubric copied from a magical handbook, a feature that is common enough on gemstones,

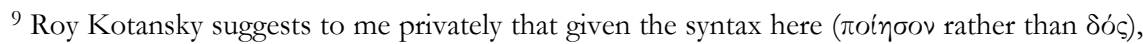

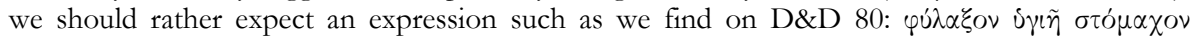

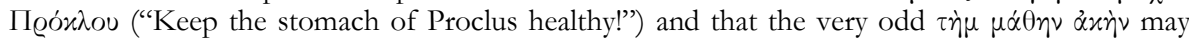
hide an accusative feminine personal name with the article ( $\tau \dot{\eta} \mu \mathrm{M} \alpha \theta \eta \nu \alpha \kappa \eta \nu)$. In this case, $\dot{\delta} \gamma \varepsilon i \eta \gamma \gamma$ would presumably be a form of the adjective (Blavatskaja, in fact, prints ijein followed by a magical symbol). In that case the first three lines of the Reverse would read: "Lord, I beg you, make Mathênakê(?) healthy with regard to her head!" Jaime Curbera informs me privately that the suffix $-\alpha x \circ \varsigma /-\alpha x \eta$ is common in personal names and suggests that Mathênakê may be related to the name Mathanos documented in Olbia; see ZGusta (1955), p. 195, \306. Kotansky's suggestion does not, however, explain the use of the article with the name. In what follows I take up an alternate idea that the stone is a miniature handbook for which the combined plea for "knowledge" (for the healer) and "healing and health" (for the patient) makes complete sense.
} 
amulets and other kinds of applied magic. ${ }^{10}$ There is, however, no exact

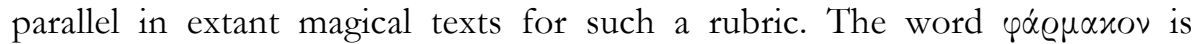
ambiguous. In magical texts of this period it can refer to both a "poison" and a "(hostile) incantation." And we do, in fact, have evidence that the Greeks used amulets to protect themselves against both. ${ }^{11}$ The closest parallel comes from a fourth-century CE magical handbook: "For the loosening of spells

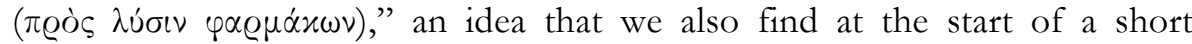
incantation to be inscribed on a three-cornered ostracon: "Asstraelos Chraelos, loosen every spell ( $\pi \tilde{\alpha} \nu \varphi \alpha \dot{\alpha} \varrho \alpha \varkappa o \nu)$ against me, so-and-so, ..."12 The verb "to loosen" ( $\lambda \dot{\varepsilon} \varepsilon \iota \nu)$ in this text and the cognate noun "loosening" ( $\lambda \dot{\sigma} \sigma \iota \varsigma)$ in the previous one both seem to imagine the undoing of some kind of binding spell or curse. The real oddity, then, is the use of $\alpha \pi o \pi \circ \mu \pi \dot{\eta}$, a noun derived from the verb $\alpha \pi 0 \pi \varepsilon \dot{\varepsilon} \mu \varepsilon \varepsilon \nu$, "to send away," which usually refers to purification rituals during which polluted materials (often called $\varphi \alpha \varrho \mu \alpha \varkappa \alpha$ ) are carried away, or to scapegoat rituals, during which polluted animals or people (often called $\varphi \alpha \varrho \mu \alpha x \circ$ i) are driven out of a town or household. ${ }^{13}$

We find, in fact, references in some magical texts to the defensive use of such rituals against the curses or malicious magic of others. The most explicit is a stipulation in a long curse from Apamea in Syria, which attempts to bind a charioteer named Hyperechius: “... if anyone made rites of expulsion or rites of

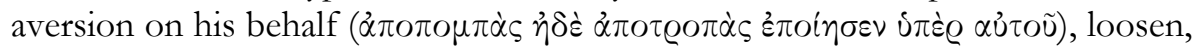
loosen completely all aid ( $\lambda \dot{\sigma} \sigma \alpha \tau \varepsilon, \dot{\alpha} \pi \circ \lambda \dot{\sigma} \sigma \alpha \tau \varepsilon \pi \tilde{\alpha} \sigma \alpha \nu \beta \sigma \dot{\eta}^{\prime}(\alpha \nu)$ made on behalf of Hyperechius, son of Remmachus, of the Blue team."14 Since this stipulation is designed to undo any possible help $(\beta \circ \eta \hat{\theta} \theta \alpha)$ that the intended victim Hyperechius may have used to protect himself against curses, it seems best to understand $\dot{\alpha} \pi \circ \pi \circ \mu \pi \dot{\alpha} \varsigma \dot{\eta} \delta \dot{\varepsilon} \dot{\alpha} \pi O \tau \varrho o \pi \dot{\alpha} \varsigma$ as repeated rituals of escort and aversion (note the plural here, as in the Anapa gem) aimed at shielding him from precisely the kind of malevolent magic that is illustrated by this lead tablet itself,

\footnotetext{
${ }^{10}$ JORDAN (2002), p. 6, for example, discusses another Russian gem, which also begins with instructions copied mistakenly from a handbook ("This is the logos") and he cites another example in the Louvre: BONNER, YOUTIE (1953).

${ }^{11}$ See, e.g., GMA 36.15-16 and 52.12, with Kotansky's comments ad locc, for amulets against poison; those against curses and hostile incantations are treated below. There is a small possibility that the word $\varphi \alpha \varrho \mu \alpha x \omega \nu$ is (with a change of accent) $\varphi \propto \varrho \mu \alpha x \tilde{\omega} \nu$, the genitive plural of the word

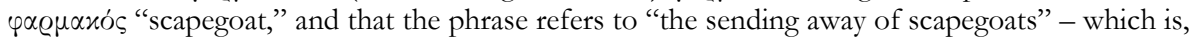
of course, precisely what one does with scapegoats (see note 13). The word is rare, however, in the Roman period and does not appear at all in magical texts, so it seems imprudent to interject it here, although (as we shall see below) scapegoat rituals are close kin to the ritual imagined by the creator of the Anapa gem.

12 PGM XXXVI, p. 256-264.

${ }^{13}$ For recent bibliography on the latter, see FARAONE (2004a). For the former, see PARKER (1983), p. 257-80.

${ }^{14}$ DT 15. The curse is fragmentary, but since the stipulation is repeated twice in lines 3-7, the text is secure.
} 
which is a curse that aims at preventing Hyperechius from winning a chariot race. ${ }^{15}$ The fact that the author of this curse uses the plural nouns $\alpha \pi 0 \pi \circ \mu \pi \alpha i$ and $\alpha \pi 0 \tau \varrho o \pi \alpha i$ in tandem further strengthens the case, since the latter ("rites of aversion") are always protective or defensive in nature. ${ }^{16} \mathrm{We}$ find a similar

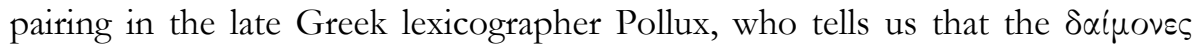

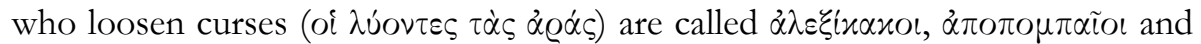
$\dot{\alpha} \pi 0 \tau \varrho o ́ \pi \alpha \iota \circ .{ }^{17}$ Thus, it would seem that the rubric $\pi \varrho o ̀ \varsigma ~ \varphi \alpha \varrho \mu \dot{\alpha} x \omega \nu \dot{\alpha} \pi 0 \pi O \mu \pi \dot{\alpha} \varsigma$ at the start of the Russian gemstone is best paraphrased as "For the sake of sending away (dangerous or hostile) spells."

The long word in the second line on the gemstone ( $\varphi \varrho \alpha \mu \varphi \varepsilon \varrho \varepsilon \iota \nu \lambda \varepsilon \lambda \alpha \mu \varepsilon)$ is probably not Greek, although at first glance the last two-thirds of it seem

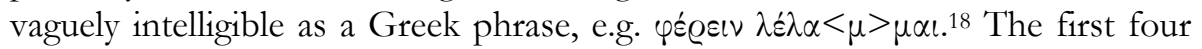
letters of the line, $\varphi \varrho \alpha \mu$ or $\varphi \varrho \alpha \nu$, are surely not Greek, but are close in form to the common way for Greeks to represent the name of the Egyptian sun-god,

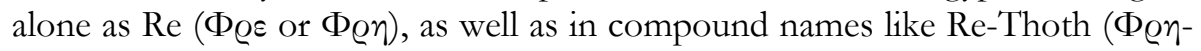
$\theta \omega o v \theta)$ or Re the Great ( $\varrho \varrho \varepsilon \omega)$. And if we take $\varphi \varrho \alpha \mu \varphi \varepsilon \varrho \varepsilon \iota$ together as a compound name, it resembles, at least in the sequence of its consonants,

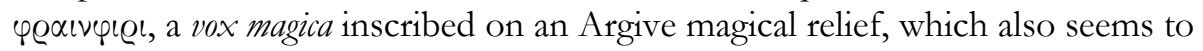
be a compound derived from $\Phi \varrho \varepsilon .{ }^{19}$ The remainder of line $2(\lambda \varepsilon \lambda \alpha \mu \varepsilon)$ is probably a magical word and may well be a variant of the word $\lambda \alpha i \lambda \alpha \mu$, popular on Greek amulets and thought to be a transliteration of a Hebrew word that

15 The use of the imperatives $\lambda \dot{v} \sigma \alpha \tau \varepsilon$ and $\dot{\alpha} \pi \partial \lambda \dot{\sigma} \sigma \alpha \varepsilon$ strengthens this impression, since (as we saw earlier) $\lambda u^{\prime} \varepsilon \nu$ is often used in the sense of "loosening" magical spells or "releasing" someone

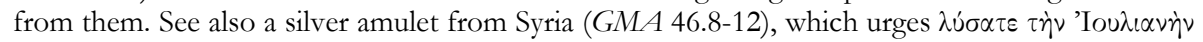

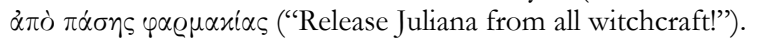

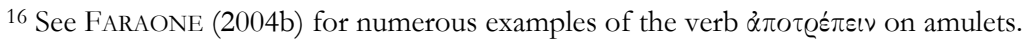

17 Pollux, Onomasticon V, 131. A magical recipe in a late-antique papyrus handbook uses the

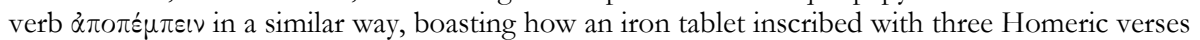

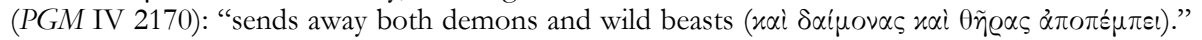
Here one might be tempted to say that the verb is being used in a more general way - like

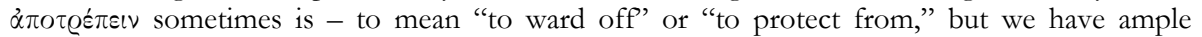
enough evidence that the Greeks performed escort rituals of this sort, for example, to deal with ghosts and haunted houses. See FARAONE (1992), p. 82-83.

${ }^{18}$ Ann Hanson suggests privately that these words could be rendered "I have been committed to carry/bear" or "I have committed myself to carry/bear." If $\varphi \varrho \alpha \mu$ or $\varphi \varrho \alpha \nu$ is (see my discussion further on) in fact the accusative form of the name of the sun-god Phre or Re, then the god may be the direct object: "I have been committed to carry/bear Re." My colleague Robert Ritner informs me by e-mail that if the Anapa gem were in scarab form or had a scarab on it, then the statement that I (= scarab) carry Re would make excellent sense, since the scarab is a solar vehicle. The same would be possible if there were an image of a boat (solar bark) or a cow (sky).

${ }^{19}$ For all of these voces magicae, see BRASHEAR (1995), p. 3601. The word $\varphi \varrho \alpha$ is admittedly less common, but it does, in fact, appear at the end of a long list of magical names in a prayer to the sun (PGM IV 284), and we find $\varphi \varrho \alpha \varphi \varepsilon \omega \nu$ on a gold lamellae from Heliopolis in Lebanon (GMA 50.3). 
means "forever." 20 It would seem, therefore, that all of line 2 is a vox magica that in some way or other invokes or acclaims an immortal solar being.

\section{The Damnameneus triangle}

The rest of the obverse of this gem is filled with a curious triangular formation formed by the name Damnameneus. The triangle is produced by writing out the name in full in the first line and then writing it again on the line beneath, but leaving off the initial letter. The process is repeated line-by-line until all of the letters are gone. There is one other example of the name Damnameneus in a wing-formation on a headache amulet. It appears in truncated form in a magical recipe for an amulet (in an early medieval Aramaic handbook from the Cairo Genizah) that, like the Russian gem, heals the head: ${ }^{21}$

$\begin{array}{lr}\text { [3 MAGICAL SYMBOLS] } & \begin{array}{r}\text { amnameneus } \\ \text { mnameneus } \\ \text { nameneus } \\ \text { ameneus } \\ \text { You holy symbols }\end{array} \\ \text { and holy charactêres } & \text { eneus } \\ \text { by the mercy of the Father of Mercy } & \text { neus } \\ \text { heal the head of such-and-such } & \text { eus } \\ & \text { us } \\ & \mathrm{s}\end{array}$

Here, although the first iteration of the disappearing name has been lost, I agree with the editors that the word should have been Damnameneus, and indeed we do find other examples in the Greek corpus of disappearing names missing their first iteration. ${ }^{22}$

In Roman times such triangular formations seem to serve two diametrically opposed purposes. ${ }^{23}$ If they are decipherable names and appear alone on curative amulets, they are usually thought to work according to the process of

20 See GMA 57.3, with Kotansky's comments. Although I can find no precise parallel for $\lambda \varepsilon \lambda \alpha \mu \varepsilon$, the range of variants of $\lambda \alpha i \lambda \alpha \mu$ found in other magical texts suggests a fairly fluid tradition into which $\lambda \varepsilon \lambda \alpha \mu \varepsilon$ on the Anapa gemstone fits comfortably, e.g.: $\lambda \alpha \iota \lambda \alpha \mu \psi$ (PGM II 117); $\lambda \alpha \iota \nu \iota \mu \mu$ (III 414); $\lambda \varepsilon \omega \lambda \alpha \mu$ (GMA 14-15); $\lambda \varepsilon \lambda \alpha \mu$ (GMA 44 and 289); and $\lambda \varepsilon \lambda \alpha \mu \psi$ (Michel 286).

21 NAVEH, SHAKED (1993), p. 192 (text), 199 (English translation quoted here) with Plate 18 (= no. 18.9.6-13a).

22 FARAONE (forthcoming 1) Chapter 1, note 15 and note 46 below. It is clear, moreover, that the layout and content of this amulet is drawn from the same Greek tradition as, for instance, a papyrus amulet from Egypt $\left(S M 21,4^{\text {th }}-5^{\text {th }} \mathrm{CE}\right)$, which has a similar triangle and three charaktêres (albeit different from the ones in the Aramaic papyrus) and contains a similar prayer:

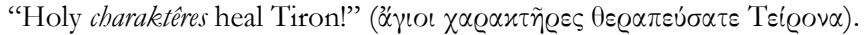

${ }^{23}$ FARAONE (forthcoming 1). 
deletio morbi: as the name of the disease or demon disappears, the disease vanishes as well. ${ }^{24}$ Similar triangular shapes on curses and erotic magical spells, on the other hand, seem to work according to a radically different principle: they are usually incomprehensible or non-Greek names and they seem to work as especially powerful instantiations of names which invoke or represent the owners of the names rather than inhibit or drive them away. On the Anapa gem and in the Aramaic amulet-recipe the focus is clearly curative. Damnameneus, moreover, is (as we shall see) a comprehensible Greek name with a very old mythological pedigree, so one would expect that on the Anapa and Aramaic amulets he is a hostile figure who causes diseases of the head and that his name and power are thus erased simultaneously.

But who is Damnameneus and why is he associated on both the Aramaic and Anapa amulets with diseases of the head? The fifth-century BCE writer Pherecydes identifies Damnameneus as one of the Idaean Dactyls (literally "Fingers"), a group which he divides into two "hands," those on the left, who

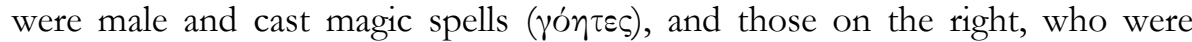
female and loosened magical spells ( $\alpha \nu \alpha \lambda \dot{o} o v \tau \varepsilon \varsigma)$. This scheme, of course, places the male Damnameneus among the sinister casters of spells, presumably those of a hostile nature. ${ }^{25}$ The female group who loosen spells may, on the other hand, perform a protective function like Photius' $\delta \alpha i \mu o v \varepsilon \varsigma$, who "loosen curses" and are called, among other names, $\alpha \pi \circ \pi \circ \mu \pi \alpha \tilde{\imath}$, " "those who send away (i.e. curses)." Similarly dangerous and chthonian connections reappear in our scanty evidence for Damnameneus in archaic epic poetry: in a fragment from the $7^{\text {th }}$ or $6^{\text {th }}$ century BCE Phoronis (a poem of unknown authorship) ${ }^{26}$ we hear that "great Damnameneus" was a wizard (үóns), a co-discoverer of iron and a servant of Adrasteia, a goddess whose name means "Inescapable" and who was herself assimilated in the classical period to Nemesis and then in the Roman-period to Ananke and Fate. Thus it would seem that a ritual $\dot{\alpha} \pi \circ \pi \circ \mu \pi \dot{\eta}$ could well be an antidote for Damnameneus and the other male Dactyls of the left hand as early as the classical period.

The word Damnameneus was also included as one of the six Ephesia grammata, powerful magical words that were used throughout the Roman Empire in oral incantations and on inscribed amulets to protect people and places: پँoxıv

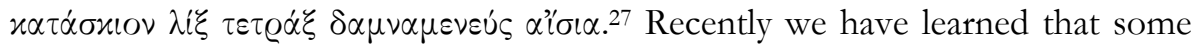

24 See e.g. Heim (1892) ad no. 97 and DornSeIFF (1925), p. 58-59 and 63-67. For full bibliographic survey, see ÖNNERFORS (1993), p. 162-67.

${ }^{25} \mathrm{FGrH} 3 \mathrm{~F} 47$ (JACOBY). The term yóntєৎ is a general word for magician or sorcerer, but

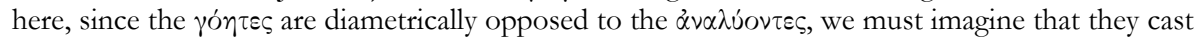
hostile spells. For recent discussions, see JOHNSTON (1999), p. 105 and BLAKELY (2007), p. 4750. Clement, Stromata, 5, 15, 132 says that the Daktyloi invented incantations (e $\pi \omega \delta \alpha i)$.

${ }^{26}$ BeRnABÉ (2003), frag. 2.3.

${ }^{27}$ For the most recent treatment with a full citation of all Greek texts, see BERNABÉ (2003). 
of the Ephesia grammata are corruptions of what were originally comprehensible Greek words on lead amulets from late-classical Crete, Sicily and Magna Graecia. ${ }^{28}$ The first two words $\alpha$ $\sigma x \iota \nu \nu ~ \varkappa \alpha \tau \dot{\alpha} \sigma \varkappa \iota \nu$, for example, now appear to be

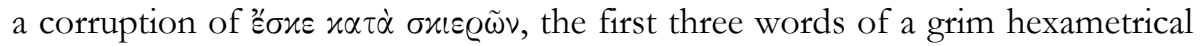
narrative about Demeter and her daughter:

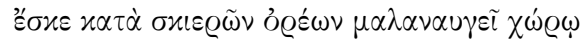

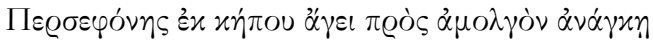

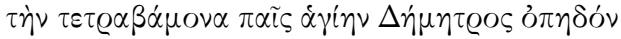

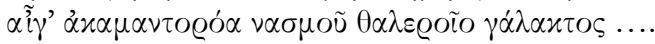

When(?) under the shadowy mountains in the dark-gleaming land a child leads of necessity from the garden of Persephone at milking time the holy four-footed servant of Demeter, the goat with her ceaseless flow of rich milk ....

Two of these amulets preserve an additional hexameter of great interest:

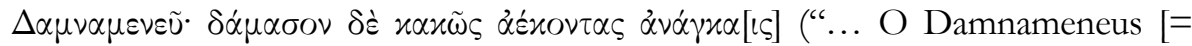
Subduer], brutally subdue the unwilling ones with constraints!") ${ }^{29}$ Here, too, the name Damnameneus (one of the Ephesia grammata) appears at the start of a verse, suggesting perhaps that the famous grammata may have originally served as incipits designed to help sorcerers recall the first verse of each section. ${ }^{30}$ If, as seems probable, this verse belongs to the same narrative as the one about Demeter and Persephone in a dark land, it seems likely that here, too, Damnameneus is a character connected with curses or other forms of chthonic constraint. Indeed, the figura etymologica ("O Subduer ... subdue!") recalls a similar appeal to another traditionally compulsive force of the underworld, who sometimes appears on curse tablets: "O Hermes Restrainer, restrain the wits, the tongue of Kallias" ("EQ $\mu \tilde{\eta}$

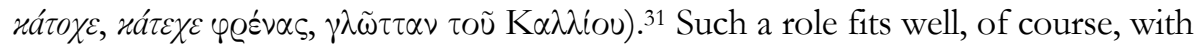
Damnameneus' membership as one of the sinister Dactyls: a yóns who casts harmful spells.

The ancients plausibly derived his name from the Greek verb "to subdue" ( $\delta \dot{\alpha} \mu \nu \varepsilon \iota \nu)$, and Clement of Alexandria claimed, on the testimony of an obscure Pythagorean named Androkydes, that the name means "the conquering sun" ( $\delta \ddot{\eta} \lambda \iota \varsigma \varsigma \delta \delta \alpha \mu \alpha \zeta \omega \nu) .{ }^{32}$ Some of the appearances of Damnameneus in the magical papyri clearly support Clement's solar explanation, ${ }^{33}$ but Bonner was

28 See the ongoing work of JORDAN (1988), (1992) and (2000).

${ }^{29}$ Line 7 of the fourth-century BCE tablet from Phalasarna, Crete, and line 8 of the fourthcentury BCE tablet from Epizepherian Locri; for text and discussion, see BERNABÉ (2003), p. 13-14.

30 See JUDGE (1987) for the similar use of incipits of psalms and gospels in magical texts as a prompt to recite the whole.

31 A third-century BCE Athenian binding spell (DTA 88).

32 Stromata, 5, 8, 45. For discussion of the solar Damnameneus, see BONNER (1950), p. 201 and BLAKELY (2007), p. 52-53.

33 His name shows up, for example, as the name of the sun in the fourth hour, when it takes the form of a bull (PGM III 510), and in a recipe for a magical ring we are told to hold the ring 
correct to stress as well Damnameneus' underworld connections in Romanera curses and hostile erotic-compulsion spells, for example, at the end of a long erotic spell addressed to Hekate-Ereschigal, where we find an invocation

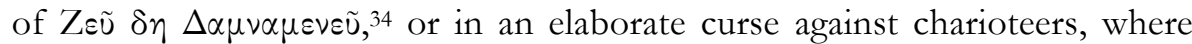
Damnameneus appears in a string of names that begins with Helios-Mithras and ends with Zeus Chthonius (Hades): $\mu \varepsilon^{\prime} \gamma \iota \tau \varepsilon \mathrm{M}^{\prime} \theta \varrho \alpha \quad \nu \alpha \mu \alpha \zeta \alpha \varrho \alpha \nu \alpha \mu \alpha \varrho \iota \alpha$

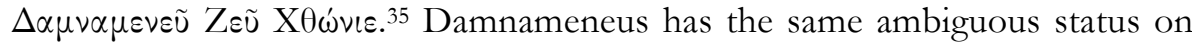
magical gemstones. ${ }^{36}$

All this suggests, then, that Damnameneus began his long career in Greek magical spells as an underworld punisher, who "subdues" the unwilling dead and presumably - given his role in curses - the living as well. Not surprisingly, he often appears together with Adrasteia, Ananke and the Fates. At some point in the Roman period, however, he probably takes on new solar powers and his name is understood to mean "the subduing sun." The evolution of Damnameneus from underworld subduer to solar deity could occur only in the Roman period, after Helios has been equated with or assimilated to the sun gods of Mesopotamia (Shamash) and Egypt (Re), who made nightly trips through the underworld and thus were themselves important underworld powers, who could for example be called upon to send up a corpse for necromantic sessions. ${ }^{37}$ A related feminine form of the name, $\Delta \alpha \mu \nu o \mu \varepsilon ́ v \eta$, designates HekateSelene, who seems to have a similarly diverse range of chthonic and cosmic associations in magical texts. ${ }^{38}$

up to the rising sun and recite a long invocation that again addresses the sun by all of its names (PGM XII 270-350).

${ }^{34}$ PGM IV 2775-2790

35 PGM III 80 and 101.

${ }^{36}$ His name appears, for example, in the nominative on the reverse of a gem of yellow jasper that has solar motifs on the obverse (BM 251), but also in the vocative on a dark-green jasper that depicts the Osiris-mummy with other chthonic symbols (BM 9). It is used most consistently, however, on gemstones connected with hostile erotic magic, appearing, for instance, twice in

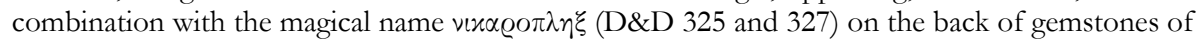
Eros, one of which depicts him burning Psyche in the form of a butterfly. Gems of this type often include in their design a statue of Nemesis, her famous wheel, or the adverb $\delta$ w $\alpha$ i $\omega$ s ("justly") all of which seem to suggest the inexorable and punitive nature of the spell. This, too, is a type of gemstone used by men to launch erotic attacks on women. See LIMC, s.v. "Adrasteia" and "Nemesis."

${ }^{37}$ FARAONE (2004c).

${ }^{38}$ Hekate-Selene in her role as Damnamenê is a lunar goddess with powers to control the cosmos, but she is also a powerful underworld deity to whom binding curses and compulsive erotic spells are addressed. The parallels with Damnameneus are striking: see, for example, her role in an erotic curse tablet (SM 49), which ends with a series of powerful names of "Lady

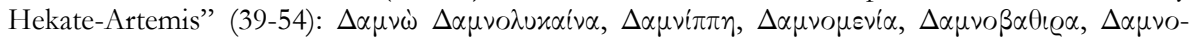

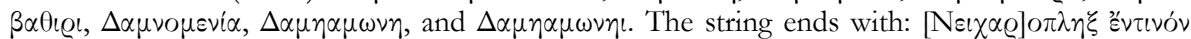

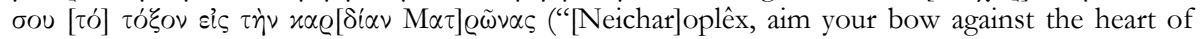
Matrôna"). See also a hymn to the goddess, where Kronos himself, in order that all the things in the cosmos remain steadfast, is said to have inscribed the scepter of Hekate with the following 


\section{Expulsive rituals}

Let us return, then, to a problem raised earlier: why does the author of the Anapa gem refer to his charm or recipe with the rubric "For the sendings-away of (hostile) charms" instead of the more common "For the loosening of (hostile) charms"? How will this heal the head of the sufferer? And how can the Damnameneus triangle accomplish either? There seems, in fact, to be slippage here between the head-diseases to be cured, the magical actions (the hostile spells

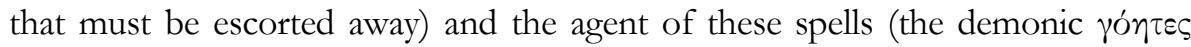
who must likewise be sent away). We see the same slippage in a long silver amulet from Beirut (4th $\mathrm{CE}$ ), where an exorcism begins with a plea to protect the owner of the amulet "from all spells ( $\varphi \alpha \dot{\alpha} \mu \alpha \alpha)$ and binding curses $(\varkappa \alpha \tau \alpha \delta \varepsilon ́ \sigma \mu \alpha \tau \alpha), "$ but

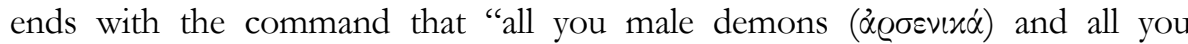
frightening binding spells ( $\varkappa \alpha \tau \delta \delta \varepsilon \delta \mu \alpha \tau \alpha)$ flee from Alexandra, whom Zoe bore (89-92) ... so you do not bewitch ( $\propto \propto \varrho \mu \alpha$ ко̃v) her (96-97)." ${ }^{9} 9$ Here the use of the verb "to flee" ( $\varphi \varepsilon u ́ \gamma \varepsilon v)$ is appropriate to a demon, who is anthropomorphically or theriomorphically imagined, but not to the $x \alpha \tau \alpha \delta \varepsilon \delta \sigma \mu \alpha \tau \alpha$. Note, too, that it is the male demons, like those Dactyls of the "left hand," who are told to flee along with the hostile spells. A similar kind of confusion or ambiguity is revealed in the rubrics of an amulet used to protect a grove of trees in Sicily: it refers to itself as a

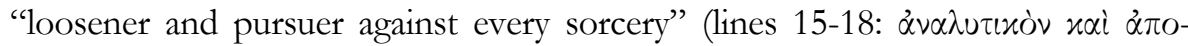

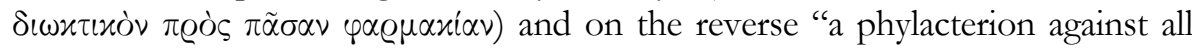

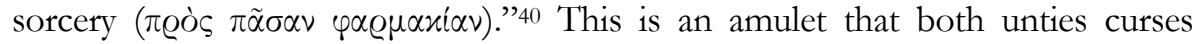

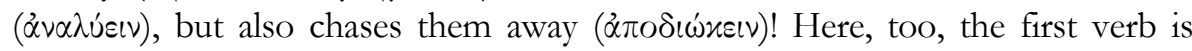
appropriate for curses, but the second only for the agents of the curse.

The language of flight and pursuit is, in fact, quite common on Greek amulets and from quite early on. A fourth-century BCE lead amulet from Crete, for example, commands: "Flee at once, flee, she-wolf, flee, dog, at once ... Raving let them run, each to his own home." The Augustan-era "Philinna Papyrus" assimilates "pain of the head" to wolf- and horse-demons and bids them to flee as well: "Flee pain of the head! [Lion] flees under a rock and wolves flee and singlehooved horses flee propelled by the blows of my perfect charm!" 41 Both charms,

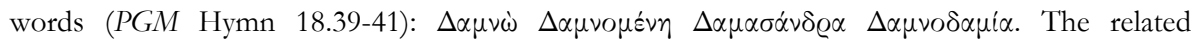

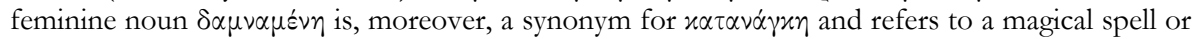
plant used in hostile magic to subdue or constrain its victims (see LSJ s.v.).

${ }^{39}$ GMA 52, lines 12-13.

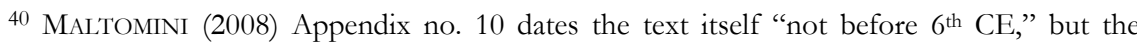
rubrics in the text itself suggest that it descends from an earlier tradition; indeed, the drawing in LIBERTINI (1927), p. 105, shows that the first rubric is indented and separated from the text in such a way as to suggest it was copied directly from a handbook.

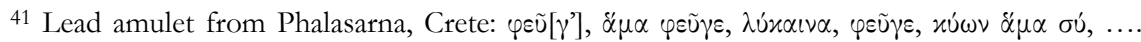

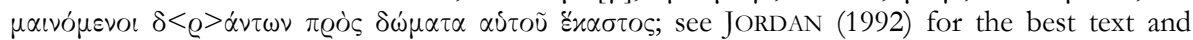

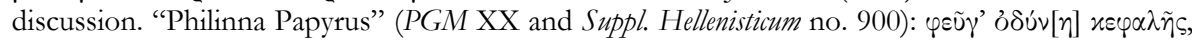


moreover, command the theriomorphic demon to go back "each to his own home" or "under a rock," that is, to the wild and uninhabited places where demons should be living. I have argued elsewhere that these formulae were originally orally performed and accompanied by some expulsive ritual or gesture, as we can see in a fragment of Aristotle, who describes a scapegoat ritual in which the plague is commanded to flee to some crows as they themselves are flying away. ${ }^{42}$ In the Roman period we find a pursuer added to the flee-formula as an additional threat. The earliest is in a cure for impetigo preserved in transliterated Greek by Pliny, in which the disease is (in this case) assimilated to beetles and told: "Flee ( $\varphi \varepsilon u ́ \gamma \varepsilon \tau \varepsilon)$ beetles, a fierce wolf pursues ( $\delta \iota \omega \dot{\varkappa \varepsilon \iota) ~ y o u ! " 43 ~ I n ~ t w o ~ c a s e s ~ t h e ~ f l e e-~}$ formula is accompanied by an image. On a gemstone depicting Perseus holding the head of Medusa, for example, one reads: "Flee gout, Perseus ( $\delta \iota \omega \varkappa \varepsilon l)$ pursues you!," and on another with Herakles strangling the Nemean Lion we find:

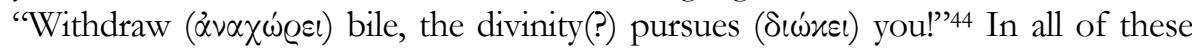
cases, then, the addressee of the command is either the disease itself ("gout" or "bile") or an animal or theriomorphic demon that is assimilated to the illness, for example, the beetles in Pliny's charm or the wild animals in the Philinna papyrus.

A similar scenario of pursuit and flight is implicit in a silver amulet for migraine:

For migraine headache:

Antaura came out of the sea. She shouted like a hind. She cried out like a cow. Artemis of Ephesus went to meet her (saying): "Antaura, where are you going?" "Into the half-part of the head (i.e. of the patient)." "No, do not go into the half part of the head!" 45

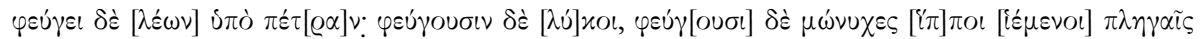

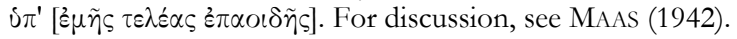

42 Aristotle, fr. 496 (ROSE): "Aristotle relates how when a plague gripped (Boeotia) and many crows came, the people hunted them down and after they had purified them with incantations

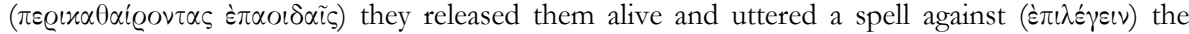

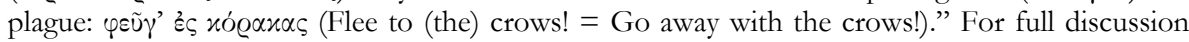
see FARAONE (2004a), p. 219.

43 Pliny, Naturalis historia XXVII, 75, 100; for the best text, see EDMONDS (1959), p. 542-544

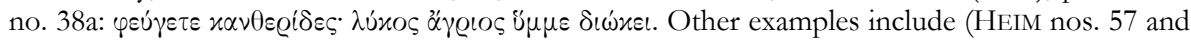
58): "Flee, flee, o bile of poison, the crested lark pursues you!" and "Flee, flee, a stronger one (i.e. a god) pursues you!"

${ }^{44}$ Heim, no. 59 and 60. I give the traditional translation here, but as PRENTICE (1906), p. 139 notes, the word $\theta \varepsilon i$ ov (if that is the right restoration) is oddly neuter here and might actually refer to "sulfur," a material that was thought to make demons flee. Amulet cases have, in fact, been found filled with sulfur, see e.g. JOHNS, POTTER (1983), p. 99 no. 30 (a gold example from the "Thetford Treasure"), who cite another example in the British Museum. Dunbabin, DickiE (1983), p. 23 discuss hollow gold foil figures of Pthonos used as pendants and mention in passing one that contained sulfur (also in the British Museum).

${ }^{45}$ GMA 13. 
As in the case of the Anapa gemstone, this text begins with a rubric. In the dramatic scene that follows the goddess confronts Antaura, a demon whose name means something like "contrary breeze." The rest of the text is a short dialogue in which Artemis questions the demon and then commands her not to enter the head of the owner of the amulet. The silver tablet breaks off here, but a series of Greek recipes of Byzantine date preserve full versions of the same dialogue, in which Jesus assumes Artemis' role; all these later Christian versions end with him ordering the demon to leave, e.g.: "Look here! Do not go into my servant, but flee ( $\varphi \varepsilon \dot{\gamma} \gamma \varepsilon \tau \varepsilon)$ and be off (í⿱㇒木 $\gamma \varepsilon \tau \varepsilon)$ to the wild mountain!" 46

In all of these "flee-formulas" the incantation itself either commands the demon to flee or quotes an authority figure (Artemis of Ephesus/Christ) in the act of doing so. The Anapa gem calls itself an $\alpha \pi о \pi о \mu \pi \dot{\eta}$, but does not, in fact, enact such a ritual in an easily recognizable manner. There are, for example, no commands to Damnameneus to flee. As it turns out, we find the same equation of disappearing name and fleeing demon in a recipe for an ivy-leaf amulet designed to cure the pain of a sore-throat. ${ }^{47}$ It appears in Chapter 18 of the Testament of Solomon, a text in which protective and curative recipes are presented as confessions that the legendary King Solomon elicits from a variety of disease-causing demons. At 18.37 the text quotes the confession of the demon responsible for sore throat and his words survive in two different versions:

\section{PAPYRUS VERSION: 48}

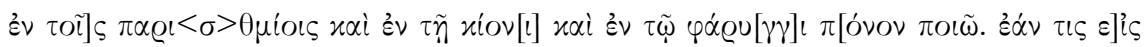

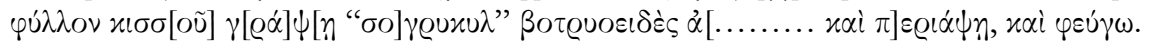

In th]e tonsils and in the uvula and in the pharynx [I cause pain. If anyone] inscribes on an ivy leaf Sogruokyl in a grape-cluster shape $[. . . . .$.$] and ties it on, I also flee.$

\section{MANUSCRIPT VERSION:49}

\footnotetext{
46 The two other versions quoted in full by Kotansky end as follows: "Go off to Mt. Ararat ... flee $(\varphi \varepsilon \tilde{\gamma} \gamma \varepsilon)$, migraine ... from the servant of the Lord" and "Depart ( $\alpha \nu \alpha \omega \dot{\omega} \varrho \eta \sigma o v)$ from the limbs and bones of God's servant."

${ }^{47}$ What follows is an abridged and simplified version of FARAONE (2009), p. 159-165.

48 I follow the brilliant reconstruction and discussion of DANIEL (1983), who uses as his guide frag. c-d, lines 15-18. A papyrus version of the spell was part of a rotulus (a vertical scroll) that contained only chapter 18 of the Testament and apparently circulated independently as a magical handbook.

${ }^{49}$ For this text, see MCCown (1922). The word $\alpha v \alpha \chi \omega$ ic is in half-brackets because it only

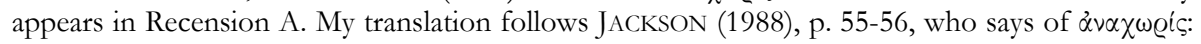

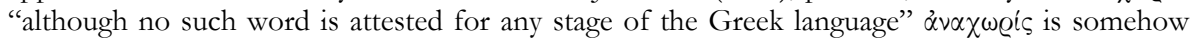
"meant to describe the process of 'withdrawing' one letter or syllable at a time from the magical word גuxoṽeyos and in this manner sympathetically to effect the demon's 'withdrawal' from his host." MASTROCINQUE (2008), p. 98-99 suggests less convincingly that the word is a mistake for
} 


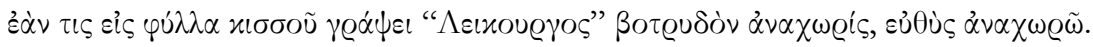

If anyone inscribes on ivy leaves Lycurgus in a grape-cluster shape receding(?), immediately I recede.

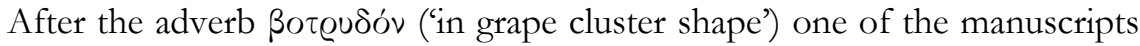
(P) adds an illustrative explanation: ${ }^{50}$

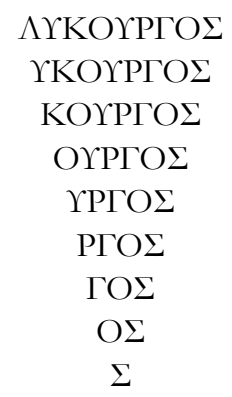

In both versions of this recipe, then, the act of inscribing the disappearing name ("If you write ....") results in the flight of the demon, using the same vocabulary that we saw in the other expulsion rituals: “... then I flee $(\varphi \varepsilon \dot{\gamma} \gamma \omega)$ " and

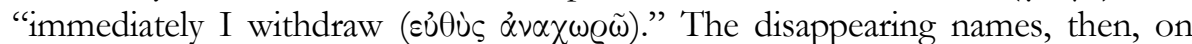
both the Anapa gem and in the Testament recipe are designed to force two demons to flee and both of them have names known from earlier Greek sources.

There seems, moreover, to be a consistent connection between illnesses of the head, demons and expulsion rites. The Augustan-era charm in the "Philinna Papyrus," as we saw, is filed under the rubric "for headache" ( and it begins with an imperative - "Flee, pain of the head!" - and then quickly assimilates this headache to wolf- and horse-demons, who flee under the blows of the speaker's incantation. The Antaura amulet, inscribed about a century later, has the rubric "for migraine" and likewise imagines a cure that is quite like an expulsive ritual: the demon who is about to enter the head of the patient is forced to flee instead to the head of a bull grazing far away on a mountain. The demoness Antaura is, moreover, assimilated to animals, when she is described as shouting "like a hind" and crying "like a cow." Damnameneus and Lycurgus, on the other hand, seem to be imagined anthropomorphically: both have a former life in Greek myth, where they performed hostile acts, and in the Roman period both are thought to be the cause of specific human pathologies, the former for the head and the latter for the throat. Both, moreover, are escorted away or otherwise forced to flee by making their name vanish.

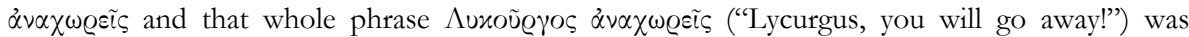
supposed to vanish.

50 Another manuscript $(\mathrm{N})$ has a version that is missing the first two iterations: КОГРГО $\Sigma$, OイPГО
} 


\section{The reverse side of the gem}

The reverse side of the gemstone begins with three lines of deferential prayer: "Lord I beg of you: grant knowledge, healing and health concerning the head." The second half of line 3 and then the remaining nine lines divide down the middle, with a different part of the head named in the genitive case on the left side and then magical symbols or magical names on the right (in the final line the word $\sigma \tau o ́ \mu \alpha \tau o \zeta$ apparently lacks its corresponding symbols or word):

\begin{tabular}{|c|c|c|}
\hline \multirow[t]{2}{*}{15} & 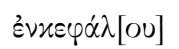 & [5 MAGICAL SYMBOLS] \\
\hline & $\omega ̈ \tau \omega \nu$ & [6 MAGICAL SYMBOLS] \\
\hline \multirow{7}{*}{20} & 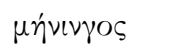 & [4 MAGICAL SYMBOLS] \\
\hline & $\sigma \tau \alpha \varphi u ́ \lambda \eta[\varsigma]$ & [3 MAGICAL SYMBOLS] $\pi \varrho \mu \eta \varrho \nu \mu \alpha$ \\
\hline & $\tau \varrho \alpha \chi \eta^{\prime} \lambda \circ u$ & $\lambda \alpha \chi \mu \alpha \lambda \eta \lambda$ \\
\hline & $\mu \varepsilon \tau \omega ́ \pi O v$ & $\lambda \alpha \varrho o \imath \mu \alpha \iota \alpha$ \\
\hline & 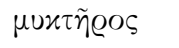 & $x \eta \varrho \varepsilon \alpha$ \\
\hline & $\pi \circ \lambda \cup ́ \pi \circ \cup$ & $\sigma \alpha \eta \eta \iota$ \\
\hline & 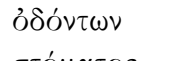 & [MAGICAL SYMBOL] \\
\hline
\end{tabular}

This part of the inscription seems to be some sort of key or code-book, that tells us which magical name or symbol we must use to cure a pain or problem in the corresponding body part. Thus, for example, if we have a patient with a sore throat, we run our finger down the left side until we reach "throat" and then we discover that the appropriate magical word is "Lachmalêl."

The magical symbols and names that appear in the right column are, unfortunately, all unknown in other extant magical texts, although there are a few near parallels. ${ }^{51}$ The order in which these ten parts of the head are listed, however, is a bit odd, and therefore significant:

51 The word $\lambda \alpha \chi \mu \alpha \lambda \eta \lambda$ (20: for the throat) sounds like some kind of angel name or Hebraized word, for which there are a few parallels, for instance, the word $\lambda \alpha \chi \alpha \mu \iota \mu \alpha \lambda_{\iota} \alpha \lambda_{l}$ inscribed twice within a tabula ansata in the field of picture of a lion-headed man gazing back at a decapitated head that he holds in his right hand (D\&D 308). See also SIJPESTEIJN (1975), p. 272 no. 3, for a black obsidian gemstone inscribed with $\lambda \alpha \chi \mu i \lambda \eta[]$ and Testament of Solomon, 8.5 for the protective angel "Lamechial." The magical word $\lambda \alpha \varrho o u \mu \alpha \iota \alpha$ (21: for the forehead), is as far as I know, completely unparalleled and the only magical word similar to $x \eta \varrho \varepsilon \alpha$ (22: for the nostril) is

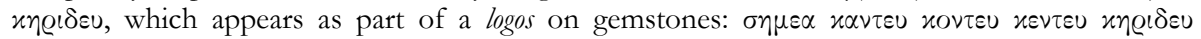

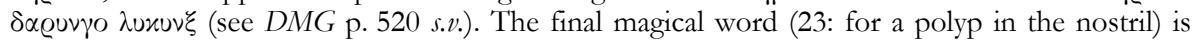
$\sigma \alpha \eta \eta \iota$. One possible parallel is a portion of the famous 100-lettered $\alpha \theta \eta \zeta \varepsilon \varphi \omega t-\log o s: \sigma \alpha \eta \sigma \iota$. 


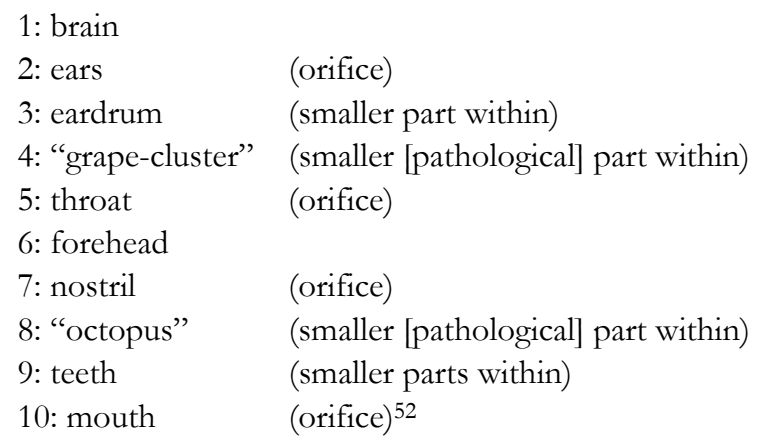

The list is apparently composed of two parallel sequences of five items, each beginning at a position on the upper part of the head (nos. 1 and 6) and then moving downwards to include two pairs of body parts. Note also that the author of this text repeatedly pairs an orifice (ear, throat, nose, and mouth) with one of its internal parts (eardrum, "grape-cluster," "octopus" and teeth), and that two of these smaller internal parts have metaphorical names that refer solely to pathological conditions. The word "grape cluster" ( $\left.\sigma \tau \alpha \varphi \nu \lambda)^{\prime}\right)$ in no. 4 refers to the uvula, which when it is swollen from infection during a sore throat resembles a tiny purple grape-cluster at the back of the throat. Likewise, the

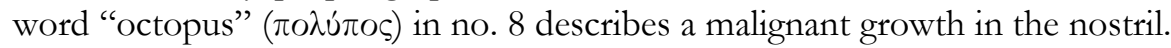

We sometimes get similar lists of body parts on curse tablets, which specify - often in great detail - the extent of the binding or paralysis intended for the victim. None of the extant examples, however, seem to follow the pattern found on this gemstone. Of those thoroughly surveyed by Versnel, only three even come close, but their differences are as telling as the similarities. ${ }^{53} \mathrm{~A}$ firstcentury BCE Latin curse, for example, lists the "neck, mouth, cheek, teeth, lips, chin, eyes, forehead and eyebrows" 54 and another the "head, forehead, eyebrows, eyelids, pupils, nostrils, lips, ears, nose, tongue and teeth." An earlier, second-century BCE, Greek curse likewise has an eclectic list: "hair, face, forehead, eyebrows, eyes, eyelids, nostrils, mouth, teeth, ears, throat and shoulders." None of these three examples, however, offer a good parallel for the Russian amulet and the prominence of the eyes or parts of the eyes on all three highlights the fact that our gemstone neglects the eyes entirely.

There is, however, a list with fairly close parallels in the Hippocratic treatise De affectionibus, which offers an eclectic survey of the parts of the human body and suggestions about what to do if the patient feels pain in a particular part ${ }^{55}$

\footnotetext{
52 Much of the discussion that follows previously appeared in FARAONE (forthcoming 2), where I argue that this gem and a series of wandering-womb amulets show how doctors and sorcerers shared many common ideas and techniques in the Roman period.

53 VERSNEL (1998).

${ }^{54}$ DT 135a.

${ }^{55}$ POTTER (1988), p. 4-5.
} 
or if that part swells up. It functions, in short, just like the Russian gemstone, except that it offers brief medical explanations and advice for treatment (both based on Hippocratic humoral theory), instead of magical symbols or names. The treatise begins with a chapter on the head (2-5), which is divided into seven sections, each devoted to a different part of the head or face. Each section begins with a somewhat formulaic conditional sentence, for example: "If pains fall upon part X, it is beneficial to do Y." The chapter is organized as follows (I give the protasis of the first sentence of each section in the chapter): ${ }^{56}$

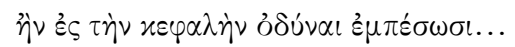

(If pains befall the head...)

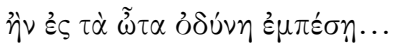

(If pain befalls the ears...)

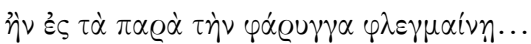

(If the area along the throat swells up...)

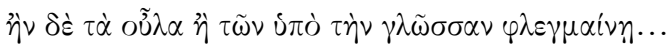

(If the gums or any of the places beneath the tongue swell up...)

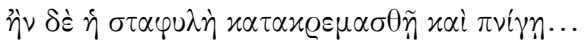

(If the inflamed uvula hangs down and chokes [i.e. the patient]...)

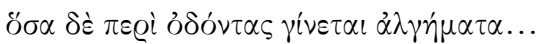

(However many pains there are around the teeth...)

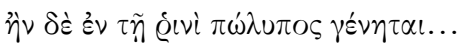

(If a polyp forms in the nose...)

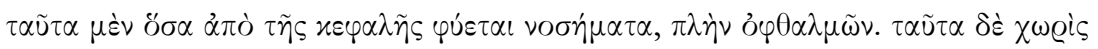
$\gamma \varepsilon \gamma \varrho \alpha \dot{\varphi} \varphi \tau \alpha \iota$.

(These are the diseases that arise from the head, except those of the eyes, which will be described separately.)

The parallels between the Hippocratic list and the magical one are significant. Both, for example, generally focus on the parts of the head that may be subjected to a pathology, but both break this pattern by listing the same two terms for pathological growths in the throat and nose: the "grape-cluster" and the "octopus." Both lists, moreover, seem interested in healing the same areas and start out, at least, in a similar order:

Gemstone:

1: brain

2: ears and eardrum

3: "grape-cluster" and throat

4: forehead

5: nostril and "octopus"

6: teeth and mouth
De affectionibus, 2-5:
1: head
2: ears
3: throat
4: gums and tongue
5: "grape-cluster"
6: teeth
7: "octopus in the nose"

${ }^{56}$ Many thanks to Lesley Dean-Jones for bringing this text to my attention. 
The list on the gemstone, as we saw, makes one trip down the sides of the head, and then returns to the top again (forehead) for a second descent down the middle of the face ending with the mouth. The list in De affectionibus 2-5, on the other hand, makes an identical first trip down the sides of the head, but then reverses direction and goes up the middle of the face and stops at the nose. Both, moreover, ignore the eyes entirely, a lapse that makes sense once we read the final line of the chapter on the head in the De affectionibus, which explains that the diseases of the eyes will be treated separately. ${ }^{57}$

\section{Amulet or miniature handbook?}

Finally, how can we connect the complicated list on the "medical" side of this amulet with its "ritual" side? At first glance there does not seem to be any connection at all. But here the parallel text from the Cairo Genizah (discussed earlier) is quite helpful, because in the Aramaic recipe an amulet inscribed with the disappearing name of Damnameneus also contains a prayer to some magical symbols "to heal the head" of the patient. It is probably not, therefore, a coincidence that the prayer on the reverse of the Anapa gem is also concerned with the head, and that the list of the body parts is limited to places on the head and face. The implication here is, of course, that diseases of the head are caused by Damnameneus, who has presumably been sent as an agent by the curses $(\varphi \alpha \varrho \mu \alpha \varkappa \alpha)$ of others. This is, I suggest, the only way we can connect the healing prayer on the reverse of the Anapa gem with the rubric on the front, which states that the gemstone is designed "for the sendings-away of (hostile) incantations." We should also ask, finally, to what genre of magical text does the Anapa gem belong? It begins and ends as if it were a handbook recipe: it starts with a rather elaborate rubric and closes with a coded list specifying body parts and pathologies to be healed. But if the author of the list on the reverse of the Anapa gemstone intended for it to be a miniature handbook, why did he reduce it to such a small size? And why did he inscribe it on a gem? I think that both questions have the same answer.

As was mentioned earlier, it is usually the case that, when handbook rubrics and short instructions show up on a gemstone or a silver amulet, we assume that they are inscribed by mistake, ${ }^{58}$ but it is surely not the case that a scribe accidentally copied nearly the whole reverse side of the Anapa gem from a handbook. What is more, to judge from other handbook recipes for amulets, the text on the gemstone strategically leaves out some important information. It does not tell us, for instance, how to use the symbols and names that appear on the list. Since the symbols, at least, are unpronounceable, we must assume that

\footnotetext{
${ }^{57}$ I am grateful to Ann Hanson for the reference to this text. For a more thorough discussion of the medical parallels and more examples, see FARAONE (forthcoming 2).

${ }^{58}$ See note 10 above.
} 
they were not spoken aloud, but rather that all were to be inscribed on some medium, and indeed Greek magical handbooks almost always specify the kind of medium - a specific type of gem, leaf, or metal tablet - on which the name or charm should be inscribed. I suggest that the author of the Anapa stone left this information out, because he has, in fact, signaled to us precisely what the medium is and precisely how it is to be inscribed: in each case we are to take an agate gemstone (i.e. the medium of the Anapa stone itself) inscribe the obverse with the solar name Phramphereinlelame followed by the Damnameneus triangle, and then inscribe the reverse with the prayer for healing. This is the all-purpose head cure. The only part of the recipe that will vary is the special set of symbols or the special magical word - e.g. for the ears or the throat or the nostrils - that will be added on the reverse of the gem to cure a specific ailment of the head. The Anapa gem is, in short, both a handbook and a model for a series of agate amulets for healing various parts of the head. ${ }^{59}$

We find similar patterns in some of the omnibus-recipes in the later papyrus handbooks. Such recipes often prescribe a primary object or text, which can then be slightly augmented or altered for different purposes. The recipe entitled "Divine Assistance from Three Homeric Verses" is a good example of the type: it starts off by directing us to inscribe three hexameters onto a tablet of iron, to speak a formula over the tablet and then to consecrate it with a special ritual. This inscribed and consecrated tablet then becomes the core of a series of different magical spells that I summarize here, highlighting the appearance of the iron tablet in each variation:

For an oracle: place under the iron tablet a laurel leaf inscribed with a spell: "ABRAA, you are the one who reveals all things MARIAPHRAX!"

For wrecking chariots: burn garlic and snakeskin and inscribe a different spell on a tin tablet that is buried in a grave for three days alongside the iron tablet. ${ }^{60}$ The spell: "NEBOUTOSOUALÊTH BEU ERBÊTH PAKERBÊTH and ÔNIOUTH overturn, so-and-so and his companions!"

For spells that restrain: inscribe a different spell on a seashell that is buried in a grave of an untimely dead person, but carry the iron tablet with you. The spell: "IÔ BOLCHOSÊTH IAKOUBIAI PATATHNAX ERBÊTH IÔ PAKERBÊTH.”

For charm- and love-spells: inscribe a different spell on a gold tablet that has been placed under the iron tablet for three days, then carry it (the gold tablet). The spell: "MYRI MYRI NES MACHESNÔN."

\footnotetext{
59 There are many examples of magical recipe-books that include a drawing as a model for an amulet or curse, but I know of only one other example of a three-dimensional model of this sort: a bronze model found in the goldsmith's shop in Alexandria, Egypt, that was apparently used to make hollow gold foil phthonos amulets; see DunBaBIN, DiCKIE (1983), p. 23.

60 The instructions here are a bit confused. Judging from the other sections, in this section the sorcerer is probably supposed to carry both the iron tablet and/or the other inscribed item (e.g. the tin tablet).
} 
For fetching spells: burn roses and sumac, then write a different spell on myrtle leaves and put them under the tablet. The spell: "STENERIÔ ARRÔRIPHRASIS YYYY I I I I, fetch her, so-and-so, for him, so-and-so!” Wear it on a woolen cord.

The shared item in all of these different recipes is the iron tablet inscribed with the three Homeric verses that in every variation is worn or carried about, or used to consecrate other inscribed objects by its touch. Note also that the iron tablet, although magically potent, is never used to perform a specific spell by itself: it needs to be enhanced by some other object and incantation that directs or focuses its power toward a specific goal. These five additional and interchangeable objects - tin or gold tablets, leaves of myrrh or laurel, or a seashell - are in each case inscribed with a different, specialized incantation that is concerned with the specific goal mentioned in the rubric, for example "oracles" or "wrecking chariots." In some cases we can easily understand the logic of the variations, for example, inscribing the "name that reveals all things" on the leaf of Apollo's favorite tree (laurel) for an oracular spell.

I suspect that a similar concept lies behind the text inscribed on the Anapa gem, although this is not made explicit: every amulet produced by this recipe will share a number of fixed features: the stone must be an agate and it must have the solar name Phramphereinlelame followed by the Damnameneus triangle on the obverse and the prayer for healing on the reverse: these four features comprise, I suggest, the core of the spell that never changes, like the iron tablet with the three Homeric verses. The scribe must, however, fine-tune this basic head amulet for more specific complaints by adding to the back of the new amulet one of the magical words or symbols that appear in the list on the back of the Anapa-gem. Thus if someone came to the magician-scribe complaining of a swollen polyp in the nose, the scribe would select a blank gemstone of the same material as his model (agate) and engrave the solar name and the disappearing Damnameneus on the obverse and the prayer on the top of the reverse. Then he would consult the Anapa sphere by running his finger down along the left side of the list until he comes to "octopus," and thereby finds the matching magical name or symbols that would direct the power of the amulet to the specific job at hand - in this case the magical word saêei. He would then presumably inscribe this word on the back of the amulet. ${ }^{61}$ If he were a clever scribe, moreover, he would avoid copying the rubric onto the front of the stone and the word "octopus" on the reverse.

Let me close by saying that the Anapa gemstone seems to illustrate nicely some of the processes that occur when - in the frenzied epigraphic habit of the

61 One might argue that the short prayer at the start of the reverse ("I beg you lord...") might also have been inscribed on back of the individual amulets, but this seems unlikely. Rather, it seems to be a prayer that was spoken aloud by sorcerer over the stone, especially since it asks the god for learning, something that in this context is more suitable for the healer than the patient. 
Roman period - amulets become repositories of miniaturized rituals and handbooks. We have indeed seen three different strategies for reducing elaborate expulsion rituals so they can fit on a small pendent. The first and simplest preserves only the flee-formula shouted at the disease by the sorcerer, for example: "Flee gout! For Perseus pursues you!" The second records a dramatic dialogue between Antaura and Artemis of Ephesus, the latter of whom eventually sends this headache demon away to the wild regions of the mountain. This amulet seems to contain what we might call a libretto for a ritual drama, which includes at the very end the standard flee-formula. In the third case, the ivy-leaf amulet for parts of the throat and the Anapa gemstone for parts of the head encapsulate expulsion rituals most concisely and abstractly by equating continued rituals of expulsion (the $\dot{\alpha} \pi \circ \pi \circ \mu \pi \alpha i$ in the Anapa rubric) to the vanishing names of Lycurgus and Damnameneus.

The anatomical codebook on the reverse of the gem displays a different kind of miniaturization, whereby the author strips the typical omnibus recipe down to its bare essentials, focusing narrowly on a list of body parts and a parallel list of curative names or symbols. Here the medium of the gem itself and the distribution of text on its surface serve as silent models for the replication of agate gemstones that likewise display the disappearing demonname Damnameneus on one side, but a different individualized word or sign on the reverse, depending on the precise part of the head. I suspect, moreover, that the absence of the eyes on this gem is significant and suggests that the author of this miniature handbook may have also created others like it, presumably on different types of gems for other areas of the body. We know, for example, that green jasper was a frequent medium for amulets used for problems in the oesophagus and stomach, ${ }^{62}$ so perhaps there lies buried in the ruins of ancient Gorgippia a small sphere of green jasper of the same diameter inscribed with similarly condensed instructions for healing the various parts of the upper digestive system, and indeed possibly a whole set of miniature handbook gems, enough to account for the entire human body and all of its manifold diseases.

Christopher A. FARAONE

The University of Chicago

Department of Classics

1115 E. $58^{\text {th }}$ St.

CHICAGO, IL 60637

E-mail: cf12@uchicago.edu

62 Bonner (1950), p. 51-60. 


\section{Abbreviations for Corpora of Magical Texts}
$G M A$
R. Kotansky, Greek Magical Amulets, vol. 1, Opladen, 1994 (Papyrologica Coloniensia, 22.1).
Heim R. HeIm, Incantamenta Magica Graeca-Latina, Leipzig, 1892 (Jabrbücher für classische Philologie Suppl. 10).
BM S. Michel, Die magischen Gemmen im Britischen Museum, 2 vols., London, 2001.
D\&D A. Delatte, P. Derchain, Les intailles magiques gréco-égyptiennes de la Bibliothèque Nationale, Paris, 1964.
DMG S. MiCHEL, Die magischen Gemmen: Eine Studie zи Zauberformeln und magischen Bilderen auf geschnitten Steinen der Antike und Neureit, Geissen, 1997.
DT A. Audollent, Defixionum Tabellae, Paris, 1904.
DTA R. WÜNSCH, Defixionum Tabellae Atticae, 1897 (IG III 3).
FGrH F. JACOBY, Die Fragmente der griechischen Historiker, Berlin/Leiden, 1923-58.
LIMC Lexicon Iconographicum Mythologiae Classicae, Zürich/Münich.
PGM K. Preisendanz, [A. Henrichs], Papyri Graecae Magicae. Die griechischen Zauber- papyri, 2 vols., Stuttgart, 1973-74².
SM R. Daniel, F. Maltomini, Supplementum Magicum, 2 vols., Opladen, 1990-91 (Papyrologica Coloniensia, 16.1 and 2).
SMA C. Bonner, Studies in Magical Amulets Chiefly Graeco-Egyptian, Ann Arbor, 1950 (University of Michigan Studies, Humanistic Series 4).

\section{Bibliography}

A. Bernabé, "La Ephesia Grammata. Génesis de una fórmula mágica," MHNH 3 (2003), p. 528.

S. Blakely, "Pherekydes' Daktyloi. Ritual, Technology and the Presocratic Perspective," Kernos 20 (2007), p. 43-67.

T. Blavatskaja, "Ein Amulet aus der Umgebung von Gorgippia," in Studia in honorem D. Decev, Moscow, 1958, p. 231-39 (in Russian with German summary).

C. Bonner, Studies in Magical Amulets Chiefly Graeco-Egyptian, Ann Arbor, 1950 (University of Michigan Studies, Humanistic Series, 4).

C. Bonner, H.C. Youtie, “A Magical Inscription on a Chalcedony,” TAPhA 84 (1953), p. 60-66.

W.M. Brashear, "The Greek Magical Papyri. An Introduction and Survey; Annotated Bibliography," $A N R W$ II, 18.5 (1995), p. 3381-3364.

R. DANIEL, "Testament of Solomon XVIII 27-28, 33-40," in Papyrus Erzherzog Rainer (P. Rainer Cent.): Festschrift zum 100-jäbrigen Bestehen der Papyrussammlung der Österreichischen Nationalbibliothek, Vienna, 1983, p. 294-304, no. 39.

A. Delatte, "Études sur la magie grecque II : un bas-relief gnostique," Le Musée Belge 17 (1913), p. 321-37.

F. DornseIFF, Das Alphabet in Mystik und Magie, Leipzig, $1925^{2}$.

K.M.C. Dunbabin, M.W. DickiE, "Invidia rumpantur pectora. The Iconography of Phthonos/ Invidia in Graeco-Roman Art," JAC 26 (1983), p. 7-37.

J.M. EDmonds, Lyra Graeca, vol. 3, Cambridge, MA, 1959. 
C.A. Faraone, Talismans and Trojan Horses. Guardian Statues in Ancient Greek Myth and Ritual, Oxford, 1992.

—, "Hipponax Frag. 128W: Epic Parody or Expulsive Incantation?,” ClAnt 23 (2004a), p. 20945.

-, "Twisting and Turning in the Prayer of the Samothracian Initiates (Aristophanes Peace 27679)," MH 61 (2004b), p. 30-50.

-, "The Collapse of Celestial and Chthonic Realms in a Late Antique 'Apollonian Invocation' (PGM I 262-347),” in R. ABusCH, A.Y. REED, P. SCHÄFER (eds.), Heavenly Realms and Eartbly Realities in Late Antique Religions, Cambridge, 2004c, p. 213-32.

-, "A Socratic Leaf-Charm for Headache (Charmides 155b-157c), Orphic Gold Leaves and the Ancient Greek Tradition of Leaf Amulets," in J. DijKstrA, J. KroEsen, Y. Kuiper (eds.), Myths, Martyrs, and Modernity. Studies in the History of Religions in Honour of Jan N. Bremmer, Leiden, 2009, p. 145-166.

-, Vanishing Acts in Ancient Greek Healing Magic. From Oral Performance to Visual Design, forthcoming 1.

-, "Magic and Medicine in the Roman Imperial Period: Two Case Studies," in G. BOHAK, S. Shaked, I. J. Yuval (eds.), Continuity and Innovation in the Magical Tradition, Leiden, forthcoming 2.

R. HeIM, Incantamenta Magica Graeca-Latina, Leipzig, 1892 (Jabrbücher für classische Philologie Suppl. 10).

H.M. JACKSON, “Notes on the Testament of Solomon,” JSJ 19 (1988), p. 19-60.

C. JOHns, T. POTTER, The Thetford Treasure: Roman Jewelry and Silver, London, 1983.

S.I. Johnston, Restless Dead. Encounters between the Living and the Dead in Ancient Greece, Berkeley, 1999.

D.R. JORDAN, “A Love Charm with Verses,” ZPE 72 (1988), p. 245-59.

—, “The Inscribed Lead Tablet from Phalasarna,” ZPE 94 (1992), p. 191-194.

—, “Three Texts from Lokroi Epizephyrioi,” ZPE 130 (2000), p. 96-101.

—, "Il testo greco di una gemma magica dall' Afghanistan (?) nel Museo Pushkin, Mosca," in A. Mastrocinque (ed.), Atti dell'incontro di studio. Gemme gnostiche e cultura ellenistica, Verona 22-23 Ottobre 1999, Bologna, 2002, p. 61-68.

E.A. JudGE, "The Magical Use of Scripture in the Papyri," in E. ConRAD, E. NewING (eds.), Perspectives on Language and Test. Essays and Poems in Honor of Francis I. Andersen's Sixtieth Birthday, Winona Lake, 1987, p. 339-349.

G. LibertinI, "Laminetta plumbea iscritta da S. Giovanni Galermo (Catania)," Rivista Indo-GrecoItalica di Filologia-Lingua-Antichità 11 (1927), p. 105-109.

C.C. McCown, The Testament of Solomon, Leipzig, 1922 (UNT 9).

P. MAAs, “The Philinna Papyrus,” JHS 62 (1942), p. 33-38.

F. Maltomini, "Due nuovi testi di magia rurale," ZPE 164 (2008), p. 159-179.

A. Mastrocinque, "Les formations géométriques de mots dans la magie ancienne," Kernos 21 (2008), p. 89-100.

J. Naveh, S. SHAKed, Magic Spells and Formulae. Aramaic Incantations of Late Antiquity, Jerusalem, 1993.

O.Y. Neverov, “Gemmes, bagues et amulettes magiques du Sud de l’URSS,” in Hommages à M.J. Vermaseren, Leiden, 1978, p. 833-48 (EPRO, 68.2).

A. ÖNNERFORS, "Magische Formeln in Dienste römischer Medizin," ANRW II, 37.1 (1993), p. $157-224$. 
R. Parker, Miasma. Pollution and Purification in Early Greek Religion, Oxford, 1983.

P. PotTer, Hippocrates, vol. 5, Cambridge, MA, 1988.

W.E. PrentiCe, "Magical Formulae on Lintels of the Christian Period in Syria," AJA 10 (1906), p. $137-150$.

P.J. SiJPESTEIJN, “Four Magical Gems,” BABesch 50 (1975), p. 272.

H.S. Versnel, "And Any Other Part of the Entire Body There May Be... An Essay on Anatomical Curses," in F. GRAF (ed.), Ansicbten griechischer Rituale. Geburtstags-Symposium für Walter Burkert, Stuttgart, 1998, p. 217-67.

L. Zgusta, Die Personennamen griechischer Städte der nördlichen Schwarzmeerkuste, Prague, 1955. 